\title{
Validation of perennial ryegrass cultivar Forage Value Index rankings using independent trial data
}

C.I. LUDEMANN ${ }^{1}$, C.M.WIMS ${ }^{1}$ and D.F. CHAPMAN ${ }^{2}$

${ }^{1}$ DairyNZ, Private Bag 3221, Hamilton 3240, New Zealand 2DairyNZ, PO Box160, Lincoln University, Lincoln 7647, New Zealand cameron.ludemann@dairynz.co.nz

\section{Abstract}

The current DairyNZ Forage Value Index (FVI) categorises ryegrass cultivar-endophyte combination into five, 'star rating' groups for dry matter (DM) yield using data from the National Forage Variety Trial (NFVT) system. However, variability in performance of cultivars between trials raises the question of how cultivars with different star ratings perform against each other under different conditions. The validity of the FVI star rating categories for perennial iyegass was assessed using cultivar DM yield data from two independent trials outside the NFVT system and under dairy cow grazing with white clover. Results from the trials were used in Monte Carlo simulations to provide a probabilistic determination of the likelihood of high FVI rated cultivars outperforming the low FVI rated cultivars. Results indicate selecting high FVI (5 star) perennial ryegrass cultivars over lower FVI (3 star) cultivars deliver greater contributions to dairy operating profit in over $94 \%$ of the simulated iterations for the Waikato and Canterbury.

Keywords: Forage Value Index, Lolium perenne, plan breeding, selection, cultivars

\section{Introduction}

Since 2012, DairyNZ has published an independent economic index, the DairyNZ Forage Value Index (FVI; www.dairynz.co.nz/fvi), that ranks perennial ryegrass (Lolium perenne) cultivar-endophyte combinations based on their expected economic value to New Zealand dairy farmers. Seasonal dry matter (DM) yield data collected from National Forage Variety Trials (NFVT) operated by the New Zealand Plant Breeding and Research Association (NZPBRA), are used to calculate the economic value of the perennial ryegrass cultivars for four regions in New Zealand: Upper North cultive Island, Lower Norh Island, Upper South Island, and Lower South Island. Based on their expected economic
value to dairy farmers, the FVI categorises cultivars by endophyte combinations into five 'star rating' groups in each dairy region. Cultivar-endophyte combinations with a higher star rating are expected to deliver greater economic value to dairy farmers (Chapman et al. 2017). Data from NFVT test differences between perennial ryegrass cultivars grown in monoculture under high nitrogen (N) supply (Lee et al. 2012). However, thi aises the possibility that cultivar rankings obtained in NFVT could change if trialled under differing management or in the presence of other species such as white clover (Camlin 1981) that may affect whole pasture performance. Furthermore, variability in performance of cultivars between NFVT sites raises per the Analysis of independent trial data in mixed swards and under grazing can, therefore, be used to test the validity of the VI star rating categories.

The objective of this research was to assess the validity of the FVI star rating categories, when perennial ryegrass cultivars are grown with white clover and managed under rotational dairy cow grazing in independent trials, using culvar vaility in performance and a probabilistic (Monte Carlo) method performance

\section{Methods}

This study utilised field experiments in Waikato (Upper North Island) and Canterbury (Upper South Island) described by Wims et al. (2014), in which 24 perennial ryegrass cultivar-endophyte combinations were grown with white clover from May 2013 until May 2016 Based on the 2017 FVI Lists (Ludemann \& Peel 2017) the cultivar-endophyte combinations were categorised according to their FVI star rating. A minimum of two according to their FVI star rating. A minimum of two cultivars with 3 years of dry matter (DM) yield data were required for a FVI star grouping to be included in eleven perennial ryegrass cultivars in Waikato (Upper North Island) and twelve in Canterbury (Upper South Island) were used in this study, and were categorised as

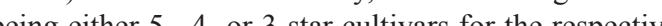
FVI VI regions (Table 1), according th ists (Ludemann \& Peel 2017).

The Waikato field experiment was located at DairyNZ Scott Farm, Hamilton $\left(37^{\circ} 47 \mathrm{~S}, 175^{\circ} 19 \mathrm{E}\right.$; altitude: $40 \mathrm{~m}$ a.s.l.; soil type: Bruntwood silt loam) and the Canterbury field experiment was located at the Lincoln University Research Dairy Farm, Lincoln, $\left(43^{\circ} 38 \mathrm{~S}, 172^{\circ} 27 \mathrm{E}\right.$ altitude: $12 \mathrm{~m}$ a.s.l.; soil type: Wakanui silt loam over 
a mottled sandy loam phase). The Waikato site was not irrigated, while at the Canterbury site $194 \mathrm{~mm}, 400 \mathrm{~mm}$ and $430 \mathrm{~mm}$ of irrigation water was applied in years 1,2 , and 3 , respectively, with a centre pivot irrigator The experiment was sown in a row-column design with four replicates on 26 April 2013 in the Waikato and on 4 April 2013 in Canterbury. Both sites were rotationally grazed by dairy cows when average herbage mass across the experimental area reached $2500-3200 \mathrm{~kg}$ $\mathrm{DM} / \mathrm{ha}$, to a post-grazing residual of $1500-1750 \mathrm{~kg} \mathrm{DM}$ ha. This resulted in 27 grazings during the experiment for the Waikato trial and 28 grazings for the Canterbury trial. Average annual nitrogen fertiliser application rates were $155 \mathrm{~kg} \mathrm{~N} / \mathrm{ha}$ and $254 \mathrm{~kg} \mathrm{~N} / \mathrm{ha}$ at the Waikato and Canterbury sites, respectively.

Herbage DM yield/ha was estimated for each cultivar directly before each grazing (except for the first grazing at the Waikato site and the first, second and last grazin at the Canterbury site) by cutting one strip (1.5 m wide by $5 \mathrm{~m}$ long) from each plot (where each plot had an area of $3 \mathrm{~m}$ wide by $11 \mathrm{~m}$ long in Waikato, and an area of $4 \mathrm{~m}$ wide by $12 \mathrm{~m}$ long in Canterbury) using a forage harvester (Haldrup $\mathrm{GmbH}$, Ilshofen, Germany) set to a cutting height of $55 \mathrm{~mm}$ above the ground. The fresh weight of the herbage was recorded in the field and a representative subsample of herbage was collected $(\sim 800 \mathrm{~g})$. In the laboratory, either duplicate subsamples of approximately $150 \mathrm{~g}$ were oven-ried $95^{\circ} \mathrm{C}$ (Waikato) or single subsamples of approximately $100 \mathrm{~g}$ were oven-dried at $60^{\circ} \mathrm{C}$ (Canterbury) to constan weight ( $\sim 8$ hours). Annual and seasonal herbage DM yield/ha for each cultivar-endophyte combination was

Table 1 Forage Value Index star rating (2016/2017) of perennial ryegrass cultivar-endophyte (Noth Isand-UNi) and Line (Upper South Island-USI) field experiments.

\begin{tabular}{lcllc}
\hline \multicolumn{2}{c}{ Waikato } & & \multicolumn{2}{c}{ Lincoln } \\
\cline { 1 - 2 } \cline { 5 - 5 } Cultivar & $\begin{array}{c}\text { Star rating } \\
\text { (UNI) }\end{array}$ & & Cultivar & $\begin{array}{c}\text { Star rating } \\
\text { (USI) }\end{array}$ \\
\hline Alto AR1 & 3 & & Abermagic AR1 & 3 \\
Bealey NEA2 & 3 & & Alto AR1 & 3 \\
Halo AR37 & 3 & & Halo AR37 & 3 \\
One50 AR1 & 3 & & One50 AR1 & 3 \\
Alto AR37 & 4 & & Bealey NEA2 & 4 \\
Arrow AR1 & 4 & & Matrix SE & 4 \\
Matrix SE & 4 & & Prospect AR37 & 4 \\
Base AR37 & 5 & & Alto AR37 & 5 \\
One50 AR37 & 5 & & Arrow AR1 & 5 \\
Prospect AR37 & 5 & & Base AR37 & 5 \\
Trojan NEA2 & 5 & & One50 AR37 & 5 \\
& & & Trojan NEA2 & 5 \\
\hline
\end{tabular}

calculated for each site and replicate, each year. Five seasons, winter, early-spring, late-spring, summer and autumn, were defined for each location as described by Chapman et al. (2017). Yields were then averaged across replicates and years to obtain representative values for each cultivar at each site. Herbage DM yields for each of the FVI star groups represented were calculated as the mean and standard deviation of the cultivars within that group.

The economic value of the cultivar-endophyte combinations were calculated from the seasonal herbage DM yield data collected from the Waikato and Canterbury field experiments using the 2016/2017 FVI economic values (Table 2) and the calculations described by Chapman et al. (2017). The difference in economic value for the 3-and 4-star cultivars, compared with the 5-star cultivars, was determined using the means and standard deviations of the seasonal DM yield data from calculated probabilistically using @RISK software version 7.5 (Palisade Corporation, Ithaca, NY, USA) over 10000 iterations of a Monte Carlo simulation. The Monte Carlo simulation method was used because it explicitly highlights the uncertainty in the results as they are calculated with levels of variation included in the outcomes. The method has also been applied to a wide range of applications where a probabilistic approach to estimate future scenarios is applicable (Metropolis 1987).

\section{Results and Discussion}

There were insufficient data available from the field experiments to compare the performance of 1- and 2-star FVI rated cultivars. Nonetheless, the analysis presented here provides information on the performance of 3-, 4- and 5-star FVI rated cultivars under simulated dairy farm management in Waikato and Canterbury.

Seasonal and annual DM yields for the cultivars evaluated are presented in Tables 3 and 4. Average annual DM yield was $8452 \mathrm{~kg} \mathrm{DM} / \mathrm{ha}$ and $14774 \mathrm{~kg}$ $\mathrm{DM} /$ ha at the Waikato and Canterbury sites, respectively. The greater annual DM yield at the Canterbury site was mainly due to greater late spring (4241 kg DM/

Table 2 Forage Value Index economic values (2016/2017) of seasonal herbage dry matter production $(\$ / \mathrm{kg}$ (UNI) and Upper south Island (USI).

\begin{tabular}{lccccc}
\hline $\begin{array}{l}\text { Dairy } \\
\text { Region }\end{array}$ & \multicolumn{5}{c}{ Economic value in each season } \\
\cline { 2 - 6 } & Winter & $\begin{array}{c}\text { Early } \\
\text { spring }\end{array}$ & $\begin{array}{c}\text { Late } \\
\text { spring }\end{array}$ & Summer & Autumn \\
\hline UNI & 0.28 & 0.45 & 0.16 & 0.34 & 0.35 \\
USI & 0.42 & 0.38 & 0.28 & 0.13 & 0.25 \\
\hline
\end{tabular}

ha versus $2176 \mathrm{~kg} \mathrm{DM} / \mathrm{ha}$ ) and summer $(6100 \mathrm{~kg} \mathrm{DM} /$ ha versus $3061 \mathrm{~kg} \mathrm{DM} / \mathrm{ha}$ ) DM yields. The annual DM yields are comparable with those reported by Chapman et al. (2016) for perennial ryegrass-white clover pasture measured using the same technique and managed under dairy cow grazing at the same sites.

For the cultivars rated as 3, 4 and 5-star in the 2017 FVI lists, average annual DM yields at the Waikato site were $7809 \mathrm{~kg}$ DM/ha, $8515 \mathrm{~kg}$ DM/ha and 9033

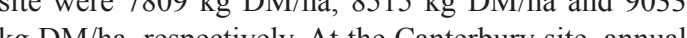
$\mathrm{kg} \mathrm{DM} / 4, \mathrm{kesectivly} \mathrm{At}$ DM yilds avecively. At $\mathrm{DM} / \mathrm{ha}$ and $15521 \mathrm{~kg} \mathrm{DM} / \mathrm{ha}$ for the 3, 4 and 5-star cultivars. The trend of increasing DM yield with star rating was reflected in all seasons at the Canterbury site and in winter, late-spring, and autumn in the Waikato.

The DM yield data of the perennial ryegrass cultivars evaluated in this study were collected from pastures where perennial ryegrass was grown with white clover and managed under rotational dairy cow grazing. Therefore, genotype $\times$ environment interactions related to management (Lee et al. 2012) and potential species interactions with white clover (Camlin 1981) that may affect herbage dry matter yields have been accounted for in this study.

Results of the Monte Carlo simulations are presented in Figures 1 and 2. Of the 10000 iterations $>94.9 \%$ indicated that the group of 5-star cultivars had a greater economic value than a group of 3-star cultivars based on DM vield data collected from the Waikato site. Using DM yields from the Canterbury site, $>97.1 \%$ of

he iterations indicated that the group of 5-star cultivars had a greater economic value than a group of 3-star cultivars. The 5-star cultivars using the Waikato dat had greater economic value than the 4-star cultivars in $75.5 \%$ of the iterations (Figure 1) and $87.5 \%$ of the iterations using the Canterbury data (Figure 2). This analysis indicates that there is a high probability that the relative economic value of perennial cultivars based on performance data collected from NFVT, and their s.ting are managed under typical dairy farm condition i.e. grown in a mixed pasture with white clover an managed under well managed dairy cow grazing.

Farmers, therefore, can be confident that selecting perennial ryegrass cultivars with a high FVI rating (5star) will deliver greater economic value to their dairy farming business than cultivars with a lower FVI.

\section{Conclusions}

This statistical analysis and probability simulations un on two independently grazed, mixed sward yield trials, align strongly with the FVI star rating information. This gives farmers further confidence that selecting high (5-star) FVI perennial ryegrass cultivars over lower FVI cultivars (when accounting for variability in seasonal DM production) will deliver greater economic benefit to dairy farmers. While 5 -star cultivars may not always perform better than 3- or 4-star rated cultivars, the probability of this occurring is low based on this study.

Table 3 The mean values $(\mu)$ and standard deviations ( $($ ) for seasonal herbage dry matter production ( $k g$ DM/ha) of 3-, 4- and 5 -star rated perennial ryegrass cultivars from the Waikato (Upper North Island) field experiment.

\begin{tabular}{lrccccr}
\hline & Winter & Early spring & Late spring & Summer & Autumn & Annual \\
\hline 3-star cultivar group $\mu$ & 823 & 928 & 2055 & 2983 & 1020 & 7809 \\
3-star cultivar group $\sigma$ & 76 & 50 & 260 & 382 & 97 & $\mathrm{n} / \mathrm{a}$ \\
4-star cultivar group $\mu$ & 1065 & 990 & 2217 & 2978 & 1265 & 8515 \\
4-star cultivar group $\sigma$ & 352 & 87 & 214 & 167 & 257 & $\mathrm{n} / \mathrm{a}$ \\
5-star cultivar group $\mu$ & 1142 & 956 & 2255 & 3224 & 1456 & 9033 \\
5-star cultivar group $\sigma$ & 142 & 95 & 246 & 292 & 372 & n/a \\
\hline
\end{tabular}

Table 4 The mean values $(\mu)$ and standard deviations $(\sigma)$ for seasonal herbage dry matter production ( $\mathrm{kg} \mathrm{DM} / \mathrm{ha})$ of 3-, 4- and 5 -star rated perennial ryegrass cultivars from the Lincoln (Upper South Island) field experiment.

\begin{tabular}{lcccccr}
\hline & Winter & Early spring & Late spring & Summer & Autumn & Annual \\
\hline 3-star cultivar group $\mu$ & 597 & 718 & 4120 & 5818 & 2840 & 14093 \\
3-star cultivar group $\sigma$ & 166 & 119 & 287 & 455 & 156 & n/a \\
4-star cultivar group $\mu$ & 736 & 780 & 4178 & 6077 & 2937 & 14708 \\
4-star cultivar group $\sigma$ & 97 & 82 & 341 & 228 & 96 & n/a \\
5-star cultivar group $\mu$ & 794 & 868 & 4425 & 6406 & 3028 & 15521 \\
5-star cultivar group $\sigma$ & 149 & 125 & 278 & 358 & 113 & n/a \\
\hline
\end{tabular}




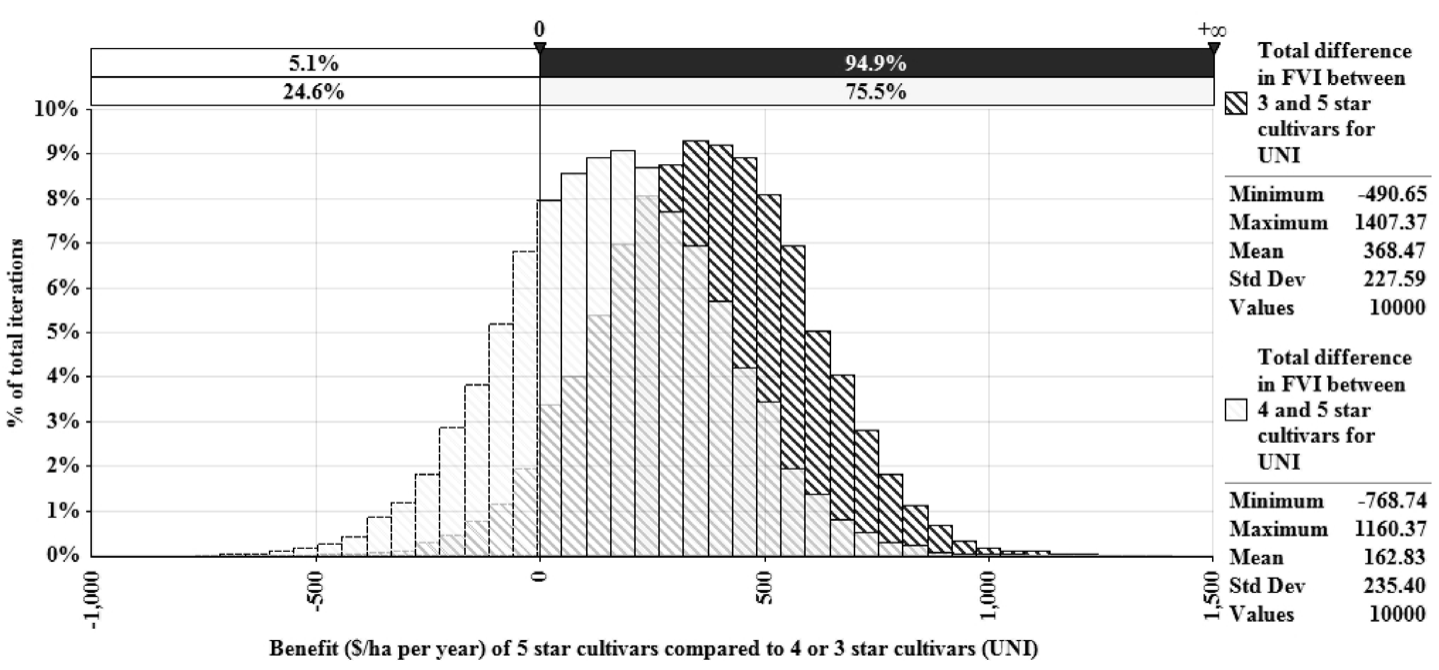

Lee, J.M.; Matthew, C.; Thom, E.R.; Chapman, D.F. 2012. Perennial ryegrass breeding in New Zealand: a dairy industry perspective. Crop and Pasture Science 63: 107-127.

Ludemann, C.I.; Peel, S. 2017. The DairyNZ FVI Handbook. DairyNZ, Newstead, New Zealand. Available at https://www.dairynz.co.nz/ media/5786645/dairynz-forage-value-indexhandbook-mar-2017.pdf [Accessed 27/02/2017].
Metropolis, N. 1987. The beginning of the monte carlo method. Los Alamos Science 12: 132-141.

Wims, C.M.; Jacobs, J.; Chapman, D.F. 2014 Determining genetic gain in pasture species: integrating multiple traits and economic values. pp. 232-234. In: Proceedings of the 5th Australasian Dairy Science Symposium.

Figure 1 Distribution of the benefits of the group of 5-star perennial ryegrass cultivars as compared with groups of 4- or 3-star (a) (values below zero indicate iterations where the 5 -star rated cultivars performed worse than the other cultivars).

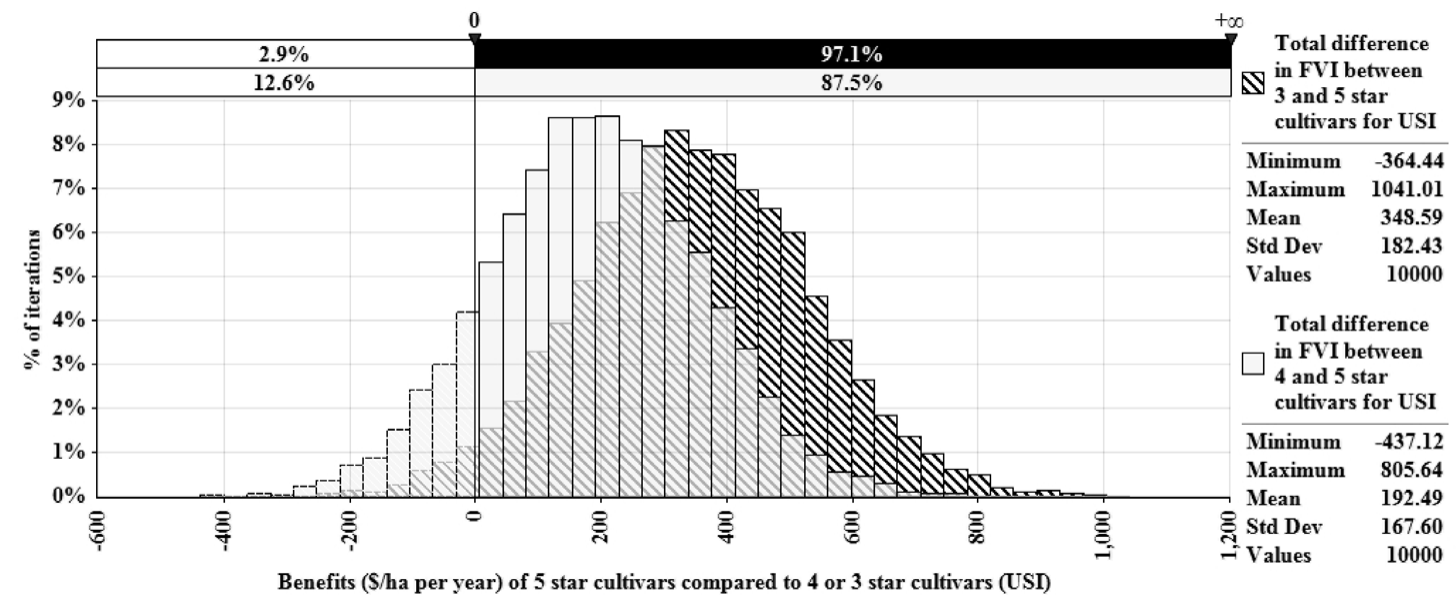

Figure 2 Distribution of the benefits of the group of 5-star perennial ryegrass cultivars as compared to groups of 4- or 3-star rated cultivars using Upper South Island (USI) field experiment data and 10000 iterations of a Monte Carlo simulation (values below zero indicate iterations where the 5 -star rated cultivars performed worse than the other cultivars).

\section{ACKNOWLEDGEMENTS}

The authors wish to thank the New Zealand Plant Breeders Association for access to the data analysed in this paper and support for the Forage Value initiative. Funding for this work was provided by New Zealan dairy farmers through DairyNZ Inc (Projects RD1414 and IS1403). The authors would like to acknowledge the technical as with the experimental field work and the statistical expertise of Barbara Kuhn-Sherlock.

\section{REFERENCES}

Camlin, M.S. 1981. Competitive effects between ten cultivars of perennial ryegrass and three cultivars of white clover grown in association. Grass and Forage Science 36: 169-178

Chapman, D.F.; Bryant, J.R.; Olayemi, M.E.; Edwards, G.R.; Thorrold, B.S.; McMillan, W.H.; Kerr, G.A.; Judson, G.; Cookson, T.; Moorhead, A.; Norriss, M. 2017. An economically based evaluation index for perennial and short-term ryegrasses in New dairy farm systems. Grass and Forage Science 72 : $1-21$

Chapman, D.F.; Lee, J.M.; Rossi, L.; Edwards, G.R.; Pinxterhuis, J.B.; Minnee, E.M.K. 2016. White clover: the forgotten component of high-producing pastures? Animal Production Science doi:10.1071/ AN16453 